\title{
DEVELOPMENT OF A MODEL SYSTEM FOR CONTROLLING THE JET GRINDING PLANT OPERATION
}

\author{
Institute of Technical Mechanics \\ of the National Academy of Sciences of Ukraine and the State Space Agency of Ukraine \\ 15 Leshko-Popel St., 49005,Dnipro,Ukraine;; e-mail: np-2006@ukr.net
}

Because of the increasing demand for fine-dispersed products in many industries, on the hand, and the high energy intensity of the grinding process, on the other hand, the problem of fine grinder productivity improvement and power consumption reduction is quite topical. The aim of this paper is to develop a system for monitoring and controlling the productivity of a jet grinding plant based on the results of acoustic monitoring of its working areas. The new approach consists in continuously monitoring the material grain-size composition and forming control actions on the circulating load of the grinding plant based on the analysis of the acoustic signals analysis from the grinding chamber.

The main factors that affect the efficiency of closed-loop jet grinding were studied, and a three-level model of the grinding process was constructed. The model accounts for the features of grinding loop, the kinetics of the material grain-size composition in the grinding chamber, and the relation between the grinding process and the acoustic signal characteristics. It was shown that increasing the yield of a finished product of a given size calls for monitoring the acoustic signals of the grinding zone and controlling the grinding chamber loading in accordance with them in order to maintain it at the optimum level. This study may be a basis for the development of an automated control system for a jet grinding plant. Installing such a system in the finished transportation zone downstream of a granulometer-type classifier would allow one to introduce an additional correction making the quality monitoring nearly continuous. From the characteristics of the recorded acoustic signals, the system automatically detects the presence of particles larger than the reference in the two-phase flow and points to the need for adjusting the classification regime. The elimination of the re-grinding probability improves the product quality and reduces the power consumption. These studies will be a basis for refining the model of an automated control system for a jet grinding plant and for its further development.

Keywords jet grinding, control, model, acoustic signals, amplitude, frequency, quality, finished product.

1. Andreev E. E., Tikhonov O.N. Raw Material Crushing, Grinding, and Dressing Preparation (in Russian). Saint Peresburg : Saint Petersburg Mining University, 2007. 439 pp.

2. Pryadko N. S. Development of the Theory of Mineral Product Fine Grinding (in Russian): D. Sc. thesis synopsis: 05.15.08, National Mining University. - Dnepropetrovsk, 2015. 36 pp.

3. Pivnyak G.G., Pilov P.I., Pryadko N.S. Decrease of Power Consumption in Fine Grinding of Minerals // Mine Planning and Equipment Selection C Drebenstedt and R. Singhal (eds), DOI: 10.1007/978-3-319-026787_104@ Springer International Publishing Switserland 2014.-Pp. 1069 -1079.

4. Lynch A. J. Cycles of Crushing and Grinding. Simulation, Optimization, Design, and Control (in Russian): translated from English. Moscow: Nedra, 1981. 343 pp.

5. Uteush E. V., Uteush Z. V. Grinding Plant Control (in Russian). Moscow: Mashinostroyeniye, 1973. - 280 pp.

6. Maryuta A. N. Automatic Optimization of the Ore Dressing Process at Magnetic Dressing Works (in Russian). Moscow: Nedra, 1975. $231 \mathrm{pp}$.

7. Chernousko F. L., Kolmanovsky V. B. Optimal Control under Random Perturbations (in Russian). Moscow: Nauka, 1978. $351 \mathrm{pp}$.

8. Gommeren H.J.C., Heitzmann D.A., Moolenaar J.A.C., Scarlett B. Modelling and control of jet mill plant Powder Technology. 2000. No. 108. Pp. 147 - 154.

9. Gorobets V. I. Parameter Optimization and the Development of a Method for Automatic Control of a Gas-Jet Mill (in Russian): Ph. D. thesis synopsis: 05.13.07, National Mining University. Dnepropetrovsk, 1972 г. $21 \mathrm{pp}$.

10. Ternovaya E. V. Bulk material in-flow grinding and transportation signal frequency analysis (in Russian). Zbahachennia Korysnykh Kopalyn. 2016, No. 63 (104). Pp. 59 - 65.

11. Muzhyka L. V., Pryadko N. S. Jet mill operation simulation and control (in Russian). Proceedings of the $9^{\text {th }}$ International Conference "Ypung Scientists 2018: from Theory to Practice (February 16, 2018, National Metallurgy Academy of Ukraine. Dnipro). - Pp. 194-197.

12. Pryadko N. S., Ternovaya E. V. Establishing the possibility of assessing the bulk material fractional composition from the frequency characteristics of acoustic signals in the flow (in Russian). Zbahachennia Korysnykh Kopalyn. 2017, No. 67 (108). Pp. 161 - 168.

Received 10.05.2018, in final form 30.05.2018 